\title{
A study of clinical characteristics and outcome of obstetric patients in intensive care and high dependency unit of a tertiary centre of Jharkhand, India
}

\author{
Samarina Kamal ${ }^{1 *}$, Vandita $\operatorname{Singh}^{2}$, Shashibala $\operatorname{Singh}^{3}$
}

\author{
${ }^{1}$ Department of Obstetrics and Gynecology, Alam Hospital and Research Centre Pvt. Ltd., Booty Raod Bariatu, Ranchi \\ Jharkhand, India \\ ${ }^{2}$ Department of Obstetrics and Gynecology, Sadar Hospital, Ranchi, Jharkhand, India \\ ${ }^{3}$ Department of Obstetrics and Gynecology, RIMS, Ranchi Jharkhand, India
}

Received: 29 September 2019

Revised: 16 December 2019

Accepted: 19 December 2019

\section{*Correspondence:}

Dr. Samarina Kamal,

E-mail: drsamrinakamal@gmail.com

Copyright: () the author(s), publisher and licensee Medip Academy. This is an open-access article distributed under the terms of the Creative Commons Attribution Non-Commercial License, which permits unrestricted non-commercial use, distribution, and reproduction in any medium, provided the original work is properly cited.

\begin{abstract}
Background: Few women during their pregnancy, labour and postnatal period require critical care related to the pregnancy itself, aggravation of a pre-existing illness and complications of the delivery. Pregnant patients account for a small number of ICU admission - 2-10\% two main indications for admission are hypertensive disorders (17.2\%$46 \%)$ and massive haemorrhage $(10 \%-32.8 \%)$. The primary objective of the present study was to review the characteristics of the obstetric patients admitted to our ICU over a 2 -year period.

Methods: It was a prospective study conducted over 50 patients in high dependency and intensive care unit at Alam hospital over a period of 2 years (October 2014 to October 2016).

Results: During the study period a total of 50 obstetric patients were transferred to the intensive care unit (ICU). Antenatal care played significant role in the obstetric outcome. $84 \%$ of patients transferred to the ICU during the study period had inadequate or no antenatal care, while $8 \%$ were booked in their pregnancy and had adequate antenatal care. ICU interventions included mechanical ventilation used in 20(40\%) patients, blood and blood product transfusion in 35(70\%) patients' inotropes in 20 patients (40\%) antihypertensive therapy in 20 patients (40\%), arterial embolization in $2(4 \%)$ patients. Maternal mortality was seen in 10 patients $(20 \%)$.

Conclusions: There is a need for training in emergency obstetrics so that the complication can be managed right at the time of occurrence.
\end{abstract}

Keywords: Haemorrhage, Haemolysis elevated liver enzymes low platelet syndrome, High dependency unit, Intensive care unit

\section{INTRODUCTION}

The majority of women during their pregnancy, labour and postnatal period require care that can be met through routine obstetric care. A small but significant number, however, require critical care. ${ }^{1}$ related to the pregnancy itself. $^{2}$ Aggravation of a pre-existing illness. ${ }^{3}$

\section{Complications of the delivery}

- When things go wrong in obstetrics, they go wrong fast-they fall off a cliff.

- One-minute mother and baby are happily savoring the view from the top, and the next they are tumbling 
over the edge and freely falling onto the rocks far below.

\section{Near miss}

A near miss obstetric morbidity means a woman (in pregnancy/labor/puerperium) who almost died but survived.

For every maternal death that occurs, between 11 and 223 women experience a 'near miss' event in pregnancy. Pregnant patients account for a small number of ICU admission - 2-10\%. Two main indications for admission are hypertensive disorders $(17.2 \%-46 \%)$ and massive haemorrhage (10\%-32.8\%). Disease severity scoring system have evolved for predicting mortality in ICU patients are Acute physiology and chronic health evaluation (APACHE2), Simplified acute physiology score (SAPS2), Sequential organ failure system and Mortality prediction modules (MPM).

Spectrum of antenatal care can be home care, outpatient antenatal care, inpatient care and critical care.

Obstetric emergencies are a challenge to the obstetrician because of the unique nature of obstetric medicine. The altered physiology of pregnancy, the presence of the fetus, the rapid deterioration of maternal and fetal condition in case of a complication, and the simultaneous management of two lives with different physiologies are a challenge. ${ }^{1}$ These emergency conditions should be managed in a well-equipped, dedicated obstetric intensive care unit (ICU) for better maternal and fetal outcomes. ${ }^{2}$

The percentage of obstetric population requiring admission to the ICU is different in different countries based on the socioeconomic status, criteria for ICU admission, availability of ICU beds, and availability of a high dependency unit. It ranges from 0.08 to $0.76 \%$ of deliveries in developed countries $3-7$ and 0.13 to $4.6 \%$ in developing countries. ${ }^{8-11}$

The mortality in these patients is high and ranges from 0 to $4.9 \%$ of ICU admissions in developed and $2-43.63 \%$ in developingcountries. ${ }^{4-7,12}$ Hypertensive disorders and obstetric hemorrhage are the two the commonest risk factors for ICU admission.7The other risk factors are sepsis, cardiac disease, and severe anemia. ${ }^{7,10,13}$ The present study was done to analyze all the obstetric admissions to the intensive care unit of a tertiary care referral hospital for a period of 2 years and to identify the risk factors responsible for admission.

In developed countries, obstetric patients only account for a small proportion $(<2 \%)$ of ICU admissions, whereas the figure is up to $7 \%$ in India and the maternal mortality ratio is also significantly higher in developing countries. ${ }^{14}$ According to the World Health Organization (WHO), "There is a story behind every maternal death or lifethreatening complication. Understanding the lessons to be learnt can help to avoid such outcomes". A better knowledge of the spectrum, characteristics, and outcomes of the diseases involving this group of patients is the first step towards achieving prevention and hence reduction of both maternal and neonatal morbidity and mortality. ${ }^{14}$

The primary objective of the present study was to review the characteristics of the obstetric patients admitted to our ICU over a 2 year period, for both obstetric-related and non-obstetric-related causes, and to assess the causes of admission, the impact of antenatal care on ICU admission, treatment and interventions during the ICU stay, obstetric outcome and the mortality rates.

\section{METHODS}

It was a prospective study conducted over 50 patients in high dependency and intensive care unit at Alam hospital over a period of 2 years (October 2014-october 2016) Inclusion criteria was critically ill women admitted during pregnancy as well as first 6 weeks of the postpartum period. The admission books of our ICU were also utilized, so as not to miss any eligible patient. The patient records, after ethical committee clearance, were then screened to ensure that when admitted, they were pregnant or within 42 days of termination of pregnancy. Each patient record was reviewed in detail. Supplementary data were accessed through the hospital's patient database.

Table 1: Presence of antepartum complications.

\begin{tabular}{|lll|}
\hline Complications & $\begin{array}{l}\text { Number of } \\
\text { patients }\end{array}$ & $\begin{array}{l}\text { Percentage } \\
\text { of patients }\end{array}$ \\
\hline Obstetric complications & & \\
\hline $\begin{array}{l}\text { Uterine and gut perforation } \\
\text { during D and E }\end{array}$ & 4 & $8 \%$ \\
\hline Adherent placenta & 2 & $4 \%$ \\
\hline Hydatidiform mole & 2 & $4 \%$ \\
\hline Gestational hypertension & 3 & $6 \%$ \\
\hline Preeclampsia & 4 & $8 \%$ \\
\hline Eclampsia + HELLP & 1 & $2 \%$ \\
\hline HELLP syndrome & 3 & $6 \%$ \\
\hline Eclampsia & 3 & $6 \%$ \\
\hline Abruptio & 4 & $8 \%$ \\
\hline AFLP & 2 & $4 \%$ \\
\hline GDM & 2 & $4 \%$ \\
\hline Ectopic pregnancy & 5 & $10 \%$ \\
\hline Medical complications & & \\
\hline Heart disease & 6 & $12 \%$ \\
\hline Dengue & 2 & $4 \%$ \\
\hline SLE & 1 & $2 \%$ \\
\hline Chronic HTN & 2 & $4 \%$ \\
\hline Overt DM & 1 & $2 \%$ \\
\hline Sickle cell disease & 2 & $4 \%$ \\
\hline Rheumatoid arthritis & 1 & $2 \%$ \\
\hline & & \\
\hline
\end{tabular}


The data retrieved for analysis included demographics, adequacy of antenatal care, co morbidities, obstetric features (antepartum history, weeks of gestation, antenatal abnormalities, mode of delivery, vital signs, and Glasgow Coma Scale score) on admission to the ICU. The causes of admission to the ICU were classified as obstetric or non-obstetric. Obstetric disorders were defined as specific pregnancy-related conditions, which occurred during pregnancy or within 42 days in the postpartum period.

Table 1 defines some of the obstetric disorders encountered in this study. Non-obstetric conditions were defined as all other conditions that were not specifically pregnancy-related. For each patient, data pertaining to ICU interventions (mechanical ventilation, haemodialysis, use of central or arterial lines, blood products/ transfusions, operations, radiological and echocardiographic examinations) were retrieved. In addition, ICU length of stay, hospital length of stay, and the outcomes of all the mothers and infants (including numbers of deaths) were recorded and analysed.

\section{RESULTS}

During the study period a total of 50 obstetric patients were transferred to the intensive care unit (ICU). The mean maternal age distribution is shown in (Figure 1). Most of the patient were primi gravida (60\%) while $40 \%$ were multi para (Figure 2).

Antenatal care played significant role in the obstetric outcome. $84 \%$ of patients transferred to the ICU during the study period had inadequate or no antenatal care, while $8 \%$ were booked in their pregnancy and had adequate antenatal care. $70 \%$ patients were in antepartum period (Figure 3). 40\% patients were in between 30-36 weeks gestation (Figure 4).

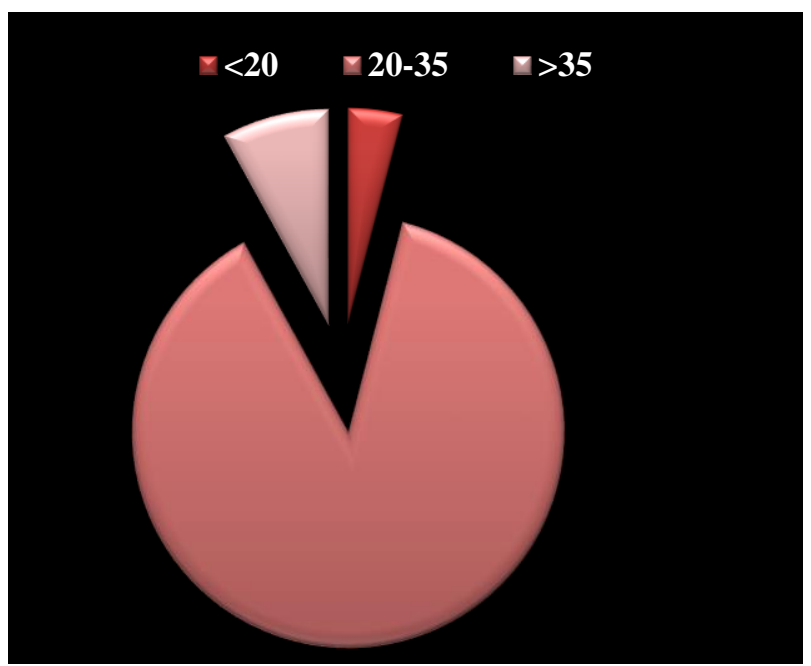

Figure 1: Age wise distribution of patients.

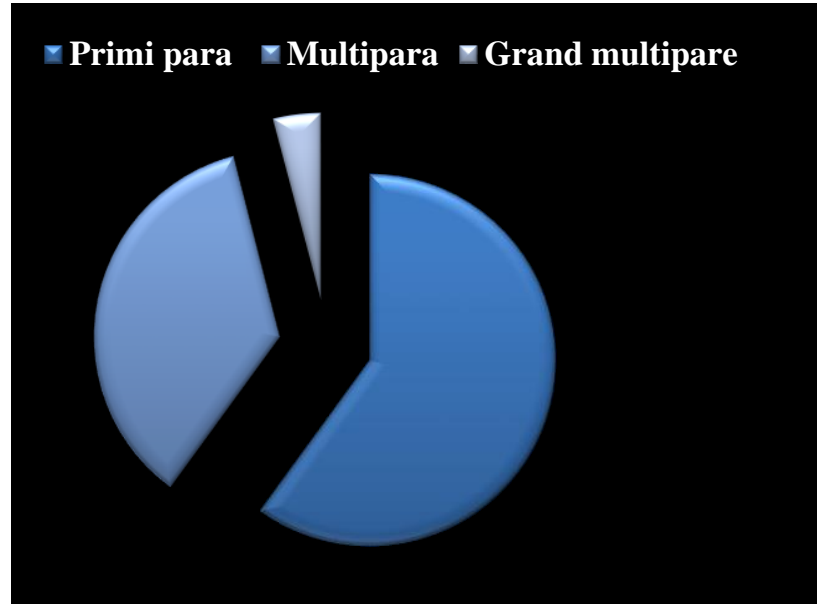

Figure 2: Parity of patients.

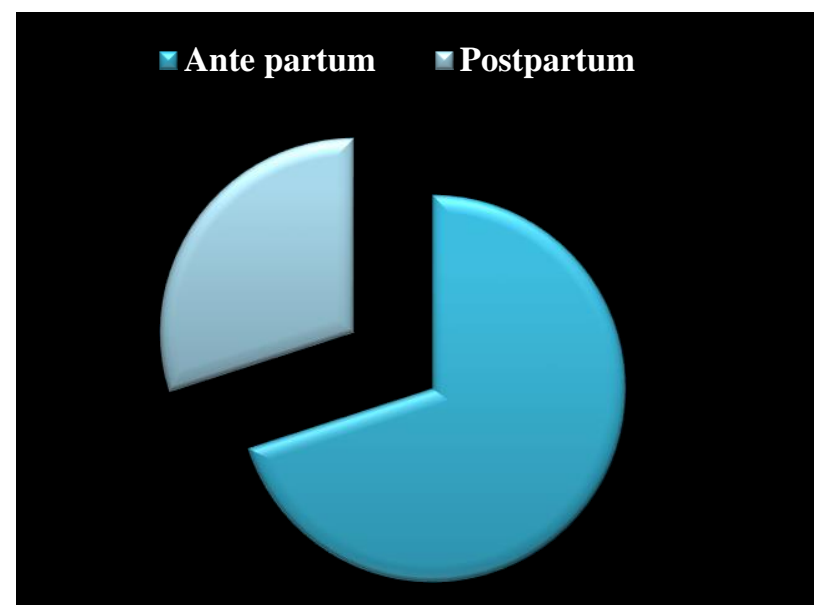

Figure 3: The time of admission.

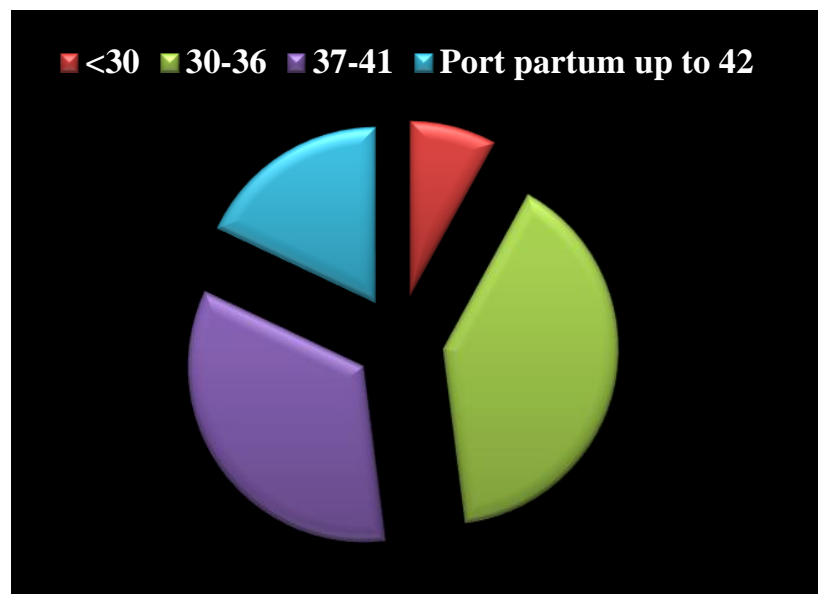

Figure 4: Gestational age (weeks) of patients.

The various antepartum obstetrics and medical complications are listed above in the following table. Gestational hypertension, preeclampsia and HELLP syndrome accounted for the majority of obstetric complications while heart disease, chronic HTN and sickle cell disease topped the list of medical complication 
of pregnancy. Blood and blood product transfusion was one of the major components of ICU care (Table 2) and $50 \%$ of patients received blood transfusion up to 10 units.

Table 2: Number of units of blood and blood products transfused to patients.

\begin{tabular}{|lll|}
\hline $\begin{array}{l}\text { Number of } \\
\text { units }\end{array}$ & $\begin{array}{l}\text { Number of } \\
\text { patients }\end{array}$ & $\begin{array}{l}\text { Percentage } \\
\text { of patients }\end{array}$ \\
\hline$<5$ & 20 & $40 \%$ \\
\hline $5-10$ & 5 & $10 \%$ \\
\hline$>10$ & 10 & $20 \%$ \\
\hline nil & 15 & $30 \%$ \\
\hline
\end{tabular}

Causes of ICU admission are shown in Table 3. Obstetric haemorrhage was the commonest cause $(36 \%)$ for admission to the ICU in this study. Hypertensive disorder in pregnancy were the second most common cause of ICU admission. The major causes in this category were eclampsia and HELLP syndrome. Among the nonobstetric cause, sepsis (24\%) accounted for the majority of admissions.

Table 3: Causes of ICU admission.

\begin{tabular}{|lcl|}
\hline Obstetric causes & $\begin{array}{c}\text { Number of } \\
\text { patients }\end{array}$ & $\begin{array}{l}\text { Percentage } \\
\text { of patients }\end{array}$ \\
\hline PPH & 15 & $30 \%$ \\
\hline PPH, DIC & 3 & $6 \%$ \\
\hline Eclampsia + HELLP & 1 & $2 \%$ \\
\hline HELLP syndrome & 3 & $6 \%$ \\
\hline Eclampsia & 3 & $6 \%$ \\
\hline Amniotic fluid embolism & 2 & $4 \%$ \\
\hline Inversion uterus & 1 & $2 \%$ \\
\hline Peripartum cardio myopathy & 1 & $2 \%$ \\
\hline Non obstetrics cause & & \\
\hline Sepsis & 12 & $24 \%$ \\
\hline Heart disease & 3 & $6 \%$ \\
\hline Pulmonary edema & 2 & $4 \%$ \\
\hline Pulmonary embolism & 1 & $2 \%$ \\
\hline Status eclampticus & 1 & $2 \%$ \\
\hline Hepatic encephalopathy & 1 & $2 \%$ \\
\hline Delayed recovery after GA & 1 & $2 \%$ \\
\hline
\end{tabular}

Table 4: Duration of mechanical ventilation needed by the patients.

\begin{tabular}{|lll|}
\hline $\begin{array}{l}\text { Number of } \\
\text { days }\end{array}$ & $\begin{array}{l}\text { Number of } \\
\text { patients }\end{array}$ & $\begin{array}{l}\text { Percentage } \\
\text { of patients }\end{array}$ \\
\hline$<1$ & 10 & $50 \%$ \\
\hline $1-2$ & 6 & $30 \%$ \\
\hline $3-4$ & 2 & $10 \%$ \\
\hline$>5$ & 2 & $10 \%$ \\
\hline
\end{tabular}

ICU interventions included mechanical ventilation used in $20(40 \%)$ patients, blood and blood product transfusion in $35(70 \%)$ patients, inotropes in 20 patients $(40 \%)$, antihypertensive therapy in 20 patients (40\%), arterial embolization in $2(4 \%)$ patients (Table 4$)$.

Table 5: Duration of hospital stay (days) in obstetric ICU/HDU.

\begin{tabular}{|lll|}
\hline $\begin{array}{l}\text { Number of } \\
\text { days }\end{array}$ & $\begin{array}{l}\text { Number of } \\
\text { patients }\end{array}$ & $\begin{array}{l}\text { Percentage } \\
\text { of patients }\end{array}$ \\
\hline$<10$ & 10 & $20 \%$ \\
\hline $10-19$ & 20 & $40 \%$ \\
\hline $20-30$ & 16 & $32 \%$ \\
\hline$>30$ & 4 & $8 \%$ \\
\hline
\end{tabular}

Most patients stayed in ICU for more than 10 days. $8 \%$ patients had to stay in ICU for more than a month (Table $5)$.

Table 6: Complications encountered by the patients while in ICU and HDU.

\begin{tabular}{|lll|}
\hline Complications & $\begin{array}{l}\text { Number of } \\
\text { patients }\end{array}$ & $\begin{array}{l}\text { Percentage } \\
\text { of patients }\end{array}$ \\
\hline Multiorgan failure & 6 & $12 \%$ \\
\hline Pulmonary edema & 3 & $6 \%$ \\
\hline Renal failure & 3 & $6 \%$ \\
\hline ARDS & 2 & $4 \%$ \\
\hline $\begin{array}{l}\text { Ventilator associated } \\
\text { pneumonia }\end{array}$ & 1 & $2 \%$ \\
\hline Hepatic coma & 1 & $2 \%$ \\
\hline Seizures & 1 & $2 \%$ \\
\hline Cardiac arrhythmias & 1 & $2 \%$ \\
\hline DVT & 1 & $2 \%$ \\
\hline
\end{tabular}

Multi organ failure happened to be the most common complication encountered in ICU followed by pulmonary edema and renal failure (Table 6).

Table 7: Maternal mortality according to etiology in obstetric ICU/HDU.

\begin{tabular}{|lcl|}
\hline Diagnosis & $\begin{array}{c}\text { Number of } \\
\text { patients }\end{array}$ & $\begin{array}{l}\text { Percentage of } \\
\text { maternal death }\end{array}$ \\
\hline PPH & 3 & $30 \%$ \\
\hline Sepsis & 2 & $20 \%$ \\
\hline DIC & 1 & $10 \%$ \\
\hline Heart disease & 1 & $10 \%$ \\
\hline Pulmonary edema & 1 & $10 \%$ \\
\hline Amniotic fluid embolis & 1 & $10 \%$ \\
\hline AFLP & 1 & $10 \%$ \\
\hline 10 patients - 20\% of admission & \\
\hline
\end{tabular}

Out of all the patients admitted, $20 \%$ could not be saved. Most common cause of death was PPH (30\%) followed by sepsis $(20 \%)$ (Table 7$)$.

Table 8 showed the various interventions in ICU. Arterial line, intensive monitoring, higher antibiotics, Blood and 
blood products and central venous line were put in most of the cases.

Table 8: Specific interventions undertaken at ICU.

\begin{tabular}{|lll|}
\hline Interventions & $\begin{array}{l}\text { Number of } \\
\text { patients }\end{array}$ & $\begin{array}{l}\text { Percentage } \\
\text { of patients }\end{array}$ \\
\hline Arterial line & 50 & $100 \%$ \\
\hline Intensive monitoring & 50 & $100 \%$ \\
\hline Antibiotics & 50 & $100 \%$ \\
\hline Central venous catheter & 35 & $70 \%$ \\
\hline Tracheostomy & 3 & $6 \%$ \\
\hline Dialysis & 3 & $6 \%$ \\
\hline Vasoactive infusions & 20 & $40 \%$ \\
\hline $\begin{array}{l}\text { Whole blood /FFP/packed } \\
\text { cell/platelet/fibrinogen }\end{array}$ & 35 & $70 \%$ \\
\hline Antihypertensive therapy & 20 & $40 \%$ \\
\hline Intubation & 20 & $40 \%$ \\
\hline Mechanical ventilation & 20 & $40 \%$ \\
\hline Arterial embolization & 2 & $4 \%$ \\
\hline
\end{tabular}

Table 9: Emergency surgical intervention in obstetric ICU patient.

\begin{tabular}{|llr|}
\hline $\begin{array}{l}\text { Ruptured } \\
\text { ectopic }\end{array}$ & $\begin{array}{l}\text { Laparotomy + } \\
\text { salpingoopherectomy }\end{array}$ & $\mathbf{5}$ \\
\hline $\begin{array}{l}\text { Perforation of gut } \\
\text { and uterus }\end{array}$ & Laparotomy + ileostomy & 4 \\
\hline $\begin{array}{l}\text { Haemoperitoneun } \\
\text { post LSCS }\end{array}$ & Laparotomy & 3 \\
\hline $\begin{array}{l}\text { Recurrent } \\
\text { secondary PPH }\end{array}$ & $\begin{array}{l}\text { Uterine artery embolization } \\
\text { and hysterectomy }\end{array}$ & 3 \\
\hline Atonic PPH & $\begin{array}{l}\text { B lynch suture, stepwise } \\
\text { devascularization, } \\
\text { hysterectomy }\end{array}$ & 5 \\
\hline
\end{tabular}

Table 9 showed the various surgical interventions in those who could not be managed conservatively. ${ }^{12}$ Cases needed laparotomy. Some patients also needed hysterectomy after uterine artery embolization and stepwise devascularization.

\section{DISCUSSION}

Early identification of critical illness essential to provide aggressive support and resuscitation including ventilator support to reduce maternal mortality.

Majority of the patients belonged to 20-35 years age group (88\%) similar to the study of Shaikh $\mathrm{S}$ et al, and Sunandagupta et al, $60 \%$ of patients were primipara contradicts with the same studies, $70 \%$ of patients were ante partum similar to $78 \%$ in study by Shaikh S et al, and Monsalve GA. ${ }^{15-17}$ Most patients in 30-36 weeks$40 \%$ some as study by Turkan Togal. ${ }^{17}$ Hypertensive disorders most important antepartum risk factor - similar to study by Kumar V. ${ }^{18}$ Most common mode of delivery caesarean section in $56 \%$ (28 patients) similar to $50 \%$ in study by Shaikh S. et al, $24 \%$ stillbirth and $12 \%$ early neonatal deaths (out of $76 \%$ live births)- higher than study of Suarez JR. ${ }^{15,19}$ Sepsis - most important non obstetric cause of ICU admission 24\%) similar to study by Shaikh $\mathrm{S}$ et al. ${ }^{16}$ Incidence of PPH and DIC - similar to study of Suarez JR and Barrete and contradicts the study by Simsek $\mathrm{T}$ where hypertensive disorder was the most common cause of ICU admission. ${ }^{15,19-21}$ The maternal mortality rate of $(20 \%)$ in patients who required mechanical ventilation was less than study by Suarez JR $(30 \%) .{ }^{19}$

\section{CONCLUSION}

Awareness should be created among the population regarding the importance of adequate antenatal care, detection of the danger signs of various obstetric complications and need for contacting medical facility at the earliest in case of emergency situations. Hence, there is a need for HDU and ICU in tertiary care hospitals. Optimum care of circulation, blood pressure and ventilation could minimize the prevalence of multiple organ failure and mortality in critically ill obstetric patients admitted in ICU.

There is a need to train obstetricians in obstetric medicine and critical care to do justice to these critically ill pregnant women. There is a need for training in emergency obstetrics so that the complication can be managed right at the time of occurrence. Training is also required for the junior doctors working in peripheral health centers in identifying at-risk cases and for timely referral.

\section{ACKNOWLEDGMENT}

Authors would like to thanks to Dr. MAR Noon, Intensivist, Critical Care Alam Hospital and Dr. Prof. Majeed Alam, proprietor Alam Hospital for their valuable suggestions coupled with profound knowledge as an incharge of medicine ICU.

\section{Funding: No funding sources \\ Conflict of interest: None declared \\ Ethical approval: The study was approved by the Institutional Ethics Committee}

\section{REFERENCES}

1. Vasquez DN, Estenssoro E, Canales HS, Reina R, Saenz MG, Neves AV, et al. Clinical characteristics and outcomes of obstetric patients requiring ICU admission. Chest. 2007;131(3):718-24.

2. Zeeman GG, Wendel GD, Cunningham FG. A blueprint forobstetric critical care. Am J Obstet Gynecol. 2003;188:532-6.

3. Sadler LC, Austin DM, Masson VL, McArthur CJ, McLintock C, Rhodes SP, et al. Review of contributory factors in maternity admissions to 
intensive care at a New Zealand tertiary hospital. Am J Obstet Gynecol. 2013;209:549.e1-7.

4. Keizer JL, Zwart JJ, Meerman RH, Harinck BI, Feuth HD, van Roosmalen J. Obstetric intensive care admissions: a 12-year review in a tertiary care centre. Eur J Obstet Gynecol Reprod Biol. 2006;128(12):152-6.

5. Zwart JJ, Dupuis JR, Richters A, Öry F, van Roosmalen J. Obstetric intensive careunit admission: a 2-year nationwide population-based cohortstudy. Intensive Care Med. 2010;36(2):256-63.

6. Wanderer JP, Leffert LR, Mhyre JM, Kuklina EV, Callaghan WM, Bateman BT. Epidemiology of obstetric-related ICU admissions in Maryland: 19992008. Crit Care Med. 2013;41(8):1844-52.

7. Baskett TF, O'Connell CM. Maternal critical care in obstetrics. J Obstet Gynaecol Can. 2009;31(3):21821.

8. Ibrahim IA, Rayis DA, Alsammani MA, Adam I. Obstetric andgynecologic admissions to the intensive care unit at Khartoum Hospital, Sudan. Int J Gynecol Obstet. 2015;129(1):84.

9. Gupta S, Naithani U, Doshi V, Bhargava V, Vijay BS. Obstetric critical care: a prospective analysis of clinical characteristics, predictability, and fetomaternal outcome in a new dedicated obstetric intensive care unit. Indian J Anesth. 2011;55(2):14653.

10. Irene YV, Vaneet K, Gurvinder K, Arun A, Lalita A. Critical care in obstetrics-scenario in a developing country. J Obstet Gynecol India. 2008;58(3):217-20.

11. Karnad DR, Lapsia V, Krishnan A, Salvi VS. Prognostic factors in obstetric patients admitted to an Indian intensive care unit. Crit Care Med. 2004;32:1294-9.

12. Tempe A, Wadhwa L, Gupta S, Bansal S, Satyanarayana L. Prediction of mortality and morbidity by simplified acute physiology score II in obstetric intensive care unit admissions. Indian $\mathbf{J}$ Med Sci. 2007;61:179-85.

13. Jain M, Modi JN. An audit of obstetric admissions to intensive care unit in a medical college hospital of central India: lessons in preventing maternal morbidity and mortality. Int J Reprod Contracept Obstet Gynecol. 2015;4(1):140-5.

14. Leung NY, Lau AC, Chan KK, Yan WW. Clinical characteristics and outcomes of obstetric patients admitted to the intensive care unit: A 10 year's retrospective review. Hong Kong Med J. 2010;16:1825.

15. Shaikh S, Shaikh NB, Abassi R, Balouch R. Obstetric admission to the intensive care unit: a one year review. Med Channel. 2013;19:59-63.

16. Monsalve GA, Martínez C, Gallo T, González MV, Arango G, Upegui A, et al. Maternal critical care: outcomes and patient characteristics in a combined obstetric high dependency unit in Medellin, Colombia. Rev Col Anest. 2011;39:190-205.

17. Togal T, Yucel N, Gedik E, Gulhas N, Toprak HI, Ercoy O. Obstetric admissions to the intensive care unit in a tertiary referral hospital. J Critical Care. 2010;25:628-33.

18. Kumar V. Critical illness in pregnancy. Med Update. 2012;22:700-10.

19. Suarez JR, Duenas C, Paternina A, Miranda J, Castillo E, Bourjeily G. Clinical characteristics and outcomes of obstetric patients requiring mechanical ventilation in Colombia. Chest. 2012;10:142.

20. Barrett H, Devin R, Clarke S, Dekker Nitert M, Boots R, Fagermo N, et al. A fifteen-year retrospective review of obstetric patients requiring critical care. Obstet Med. 2012;5:166-70.

21. Simsek T, Eyigor C, Uyar M, Karaman S, Moral AR. Retrospective review of critically ill obstetrical patients:a decade's experience. Turk J Med Sci. 2011;41:1059-64.

Cite this article as: Kamal S, Singh V, Singh S. A study of clinical characteristics and outcome of obstetric patients in intensive care and high dependency unit of a tertiary centre of Jharkhand, India. Int J Reprod Contracept Obstet Gynecol 2020;9:394-9. 